Research Article

César Neves*

\title{
Decorated or Undecorated: Analysis of the Early-Middle Neolithic Transition in Western Iberia Through the Ceramic's Stylist Techniques and Decorative Motifs
}

https://doi.org/10.1515/opar-2020-0171

received December 15, 2020; accepted July 4, 2021

\begin{abstract}
In this article, we study the role played by pottery production in the transition from Early Neolithic to Middle Neolithic in Western Iberia ( 4500-3300 cal BC) based on a critical analysis of the available empirical data. We establish a chronological and cultural sequence for this period, regarding which the historical problematic is still poorly defined due to a lasting absence of scientific discussion about the long Neolithisation process. During the evolved Early Neolithic ( 5200-4500 cal BC), archeological record shows regional specificities and cultural identities in human groups occupying a vast territory. Pottery collections evidence the strong social importance of decorative grammars, marked by a wide variety of techniques and decorative patterns. In quantitative terms, decorated vessels largely prevail over undecorated vessels. However, in the following chrono-cultural phase, the Initial Middle Neolithic $(4500-3700 \mathrm{cal}$ $\mathrm{BC})$, it starts an increasing prevalence of undecorated vessels over decorated. Decorative systems prefer the incision technique to impression (dominant in the Early Neolithic). Recurrent use of an incised motif called incised line below the rim. In this period, this type of decoration prevails in the set of decorated pottery and is found in different geographic contexts. This adds consistency to the interpretation according to which the same artifact collections are found in all settlements of the initial Middle Neolithic. Finally, by the time of the firstknown Megalithic burials - Full Moment of the Middle Neolithic (3700-3300 cal BC) - the decorative grammars almost disappear from pottery sets, which became more "common" and missed some of their symbolic and social meaning. Undecorated vessels prevail even more strongly than in the previous period.
\end{abstract}

Keywords: Middle Neolithic, pottery decoration, undecorated pottery, incised line below the rim

\section{Introduction}

The transition from the evolved Early Neolithic to the Middle Neolithic in western Iberia begins during the second half of the 5th millennium and ends in the first half of the 4th millennium cal BC, with the emergence of the first funerary megalithic monuments.

In contrast with the dynamics of the early stages of the Neolithisation process - where cultural identities are well established - the Middle Neolithic in Western Iberia ( 4500-3300 cal BC) seems to be

Special Issue: THE EARLY NEOLITHIC OF EUROPE, edited by F. Borrell, I. Clemente, M. Cubas, J. J. Ibáñez, N. Mazzucco, A. Nieto-Espinet, M. Portillo, S. Valenzuela-Lamas, \& X. Terradas

\footnotetext{
* Corresponding author: César Neves, UNIARQ - Centre of Archaeology of the University of Lisbon, Faculdade de Letras Universidade de Lisboa, Alameda da Universidade, 1600-214 Lisboa, Portugal, e-mail: c.augustoneves@gmail.com
} 
characterized by a large "social coherence." This is shown by the uniformity of domestic and grave goods material culture, which is the same throughout a very broad territory (Neves, 2010, 2015b, 2018).

From the review of the ceramic collections available, this article reflects an analysis of the pottery production during the Early Neolithic/Middle Neolithic transition in western Iberia ( 4500-3300 cal BC), in an attempt to define a chrono-cultural sequence for this moment, which still reveals undefined historical issues, due to the result of a long absence of the scientific debate around the Neolithisation process, more focused in the beginning stage.

The pottery decoration, as well as the absence of it, as a symbol of change, social identity of a community, and a certain chrono-cultural phase, presents itself as the central theme of this analysis. Since the morphological criteria were not a clear indicator of temporal, spatial, cultural, and social variability (Manen, 2002, p. 125), the review and critical analysis of the available ceramic assemblages, from the end of the Early Neolithic to the Middle Neolithic period, was based on the style and decorative techniques.

This analysis is exclusively based on habitat contexts, adopting a social-oriented approach to pottery decoration in the early phases of Neolithic in Western Iberia, from a clearly postprocessual stand (Hodder, 1982). In our view, the presence of a given motif or stylistic theme and the absence of others, the predominance of a technique over others, and then the total absence of decoration are both chronological indicators and markers for establishing different group identities, especially until the late phases of the Early Neolithic: "Decoration is therefore a means to mark the difference between two social units while strengthening the group's internal solidarity.” (Alarcão, 1996, p. 23).

Ascertaining the main reason why pottery is either decorated or undecorated will always be difficult and so is the meaning of the chosen motifs.

However, the existence of stylistic variability in different regional areas (as found in the late 6th millennium and the beginning of 5th millennium cal BC) marks the difference between groups and is simultaneously a symbol of social identities. This trend, typical of the late Early Neolithic, is followed by a growing homogeneity of decorative themes in a broad geographical space, up to a moment when graphic monotony gives rise to pottery collections almost entirely deprived of decoration (Neves, 2018). This happened precisely at a time - the Middle Neolithic - in which symbolic manifestations had their foremost expression, i.e., funerary Megalithism, around 3600 cal BC (Boaventura, 2009, 2011).

An integrated approach to the available empirical evidence demonstrates a "cycle of decorated ceramics" in the first phase of the Neolithisation process in Western Iberia, apparently showing certain regional patterns, regarding decorative grammars, followed by a "cycle of undecorated ceramics," in the Full Moment of the Middle Neolithic, and chrono-cultural meaning will be discussed in this article (Figure 1).

\section{Data and Methods}

The data presented in this article provided by the full analysis of the archaeological evidence recovered in the excavation of the Middle Neolithic sites of Monte da Foz 1 and Moita do Ourives (Benavente, Portugal). Located in the left bank of the Lower Tagus Valley, Monte da Foz 1, and Moita do Ourives are two open air settlements identified during the rescue archeological fieldwork carried out for an highway construction (Neves, Rodrigues, \& Diniz, 2008a, 2008b).

The study of these sites allowed setting Monte da Foz 1 in the Initial Middle Neolithic and Moita do Ourives in the next chronological phase, the Full Moment of the Middle Neolithic (Neves, 2010, 2018). In addition to the scientific value of identifying occupations related to the Middle Neolithic in this specific region of Wester Iberia (10 km apart of each other), the main relevance of Monte da Foz 1 and Moita do Ourives results from their being single-phase occupations, with two distinct moments, but with chronocultural evolution among themselves. This characteristic allowed to define the material culture of the Initial Middle Neolithic and the Full Middle Neolithic ( 4500-3300 cal BC), noticing their possible similarities or differences in a conceptual, symbolic and material framework of an evolutionary nature. It was also from the full analysis of Monte da Foz 1 and Moita do Ourives artefactual sets that were defined the material 


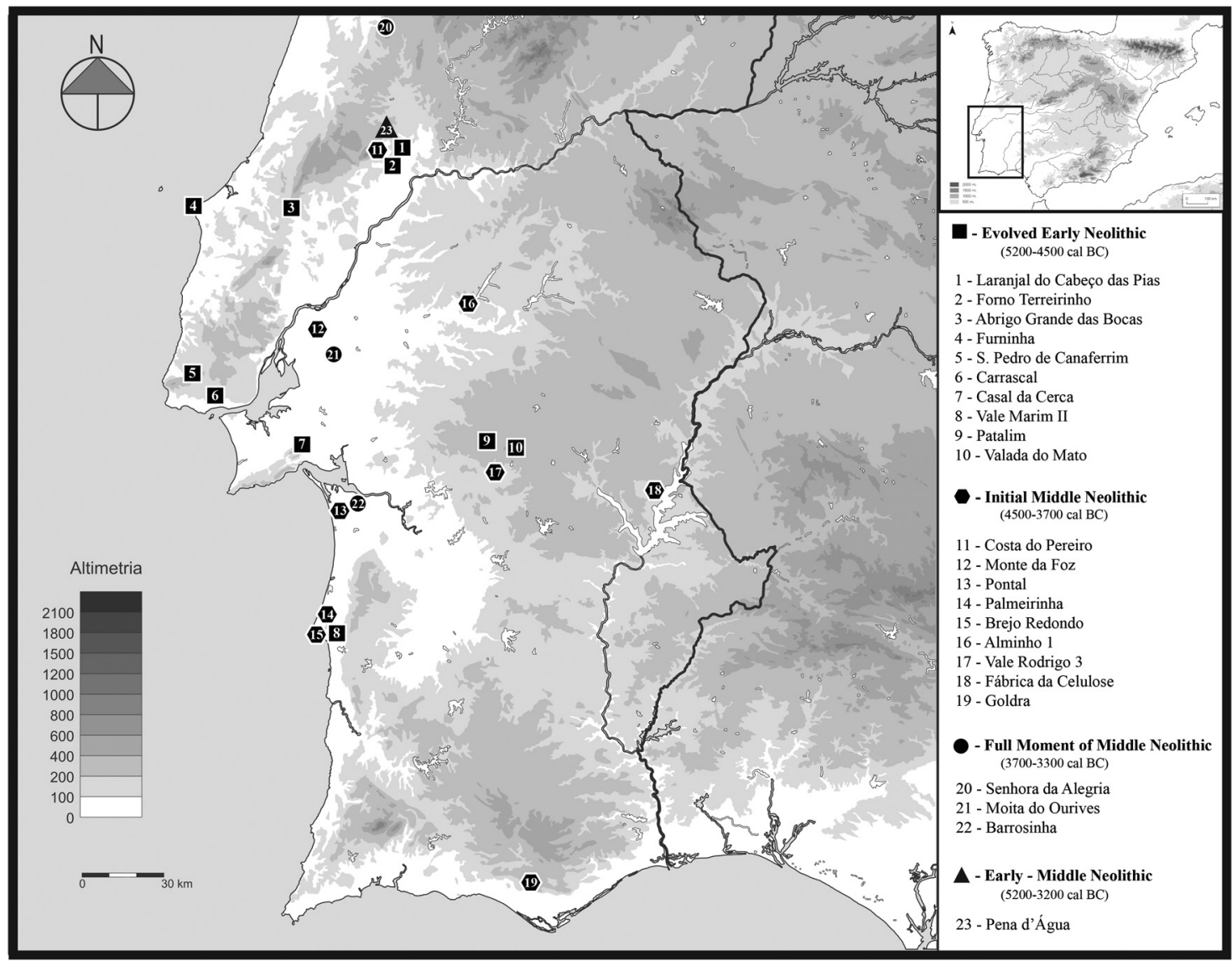

Figure 1: Archeological sites mentioned in text ( 5200-3300 cal BC) (basemap: Boaventura, 2009; Trabajos de Prehistoria for the map of Iberia).

culture typological parameters of the two distinct moments of the Middle Neolithic in Western Iberia (Neves, 2018).

With Monte da Foz and Moita do Ourives, occupations as a starting point were analyzed all available data, presented in all types of bibliography, identified as Middle Neolithic domestic contexts ( 4500-3300 cal BC), for the current Portuguese territory. Thus, this study carried out a detailed observation of the ceramic collections from 11 sites of the Initial Middle Neolithic ( 4500-3700 cal BC) and from three sites of the Full Moment of the Middle Neolithic ( $3700-3300$ cal BC).

In order for this study to have a more solid empirical basis, the reflection carried out went back to the final stage of the Early Neolithic in Western Iberia ( 5200-4500 cal BC), trying to identify the changes/ continuities between two stages of the Neolithisation process and, in this way, following the evolutional process with repercussions of sociocultural nature associated with pottery productions. For that reason, nine sites from the Evolved Early Neolithic were considered for this analysis (Figure 1).

The study followed the methodology adopted for the analysis of pottery production at Monte da Foz 1 and Moita do Ourives (Neves, 2016, 2018). From the total set of pottery vessel fragments, a subset was selected with all elements that include culturally meaningful information: decorated and undecorated rims; decorated body sherds; handles and other plastic applications. After its formation, the percentage of decorated elements and undecorated ones was calculated. Then, the presence of different decoration techniques and motifs was found at different chrono-cultural moments, which are the most and least recurrent within the pottery collections.

With all data accounted for and organized, the first observation and knowledge were produced in a regional perspective extending, in a following step, to a broader territory. A comparative analysis of the statistical data 
was carried out between three specific geographical areas (Portuguese Estremadura, Southwest Coast and Alentejo Inland), for the cultural phases in discussion: the Evolved Early Neolithic, the Initial Middle Neolithic, and Full Moment of the Middle Neolithic. In this article, we chose to illustrate the analysis with only a site from each of these geographical areas, privileging the ones with radiocarbon date.

The settlements referenced in the chrono-cultural range are under debate, but the available data that did not allow the precise accounting of the pottery elements were not included in this analysis.

\section{Results}

\subsection{Evolved Early Neolithic ( 5200-4500 cal BC)}

The oldest pottery productions identified in the current Portuguese territory $(\sim 5500-5400 \mathrm{cal}$ BC - Carvalho, 2011, p. 237) are abundantly decorated vessels, mainly by impression, of which a small number are cardial ware, despite rare exceptions such as Cabranosa (Cardoso, Carvalho, \& Norton, 1998). The common scarce presence and the relative simplicity of the decorative grammars found in these ceramics have always been an obstacle against the classification of this Early Neolithic as fully Cardial - albeit its undeniable connection to this universe.

The next chrono-cultural phase, in which we begin our study, is generally called "evolved" or "epicardial" Early Neolithic, depending on researchers. It starts in the late 6th millennium and covers the first half of the 5th millennium cal BC ( $5200-4500 \mathrm{cal} B C)$. In this period, pottery productions in the central and southern regions of current's Portuguese territory are formally and stylistically different from the productions of the previous period (Silva \& Soares, 1981; Zilhão, 1992; Zilhão \& Carvalho, 1996).

Studying pottery collections large enough to allow for a quantitative analysis, we could determine that the decorative grammar of vessels is diversified in this specific period depending on the regional area under study (Diniz \& Neves, 2018, p. 532). This diversity of options in material culture, more evident in the decorative themes of ceramic vessels, may reveal the existence of regionalisms and mirror the difference among distinct social units, while simultaneously showing the existence of inter-group solidarities (at least in social and cultural terms). In this period, it may also reveal the presence of "cultural identities" portraying “...different geographical origins, spatial trajectories and modalities of cultural interaction” (Diniz, 2003, p. 38).

In Portuguese Estremadura, pottery collections are different from those identified in synchronous contexts due to the prevalence of vessels with impressed decoration. Their decorative themes are incised bands filled with short diagonal impressions, bifid handles, and incised lines with a "fish spine" pattern, features that converge in general to the so-called Furninha-Horizon proposed by Guilaine and Ferreira (1970, pp. 315-316, 320; Cardoso \& Carvalho, 2010/2011). In this specific regional area, one of the most recurrent decorative themes of this period and region arises, i.e., the cereal stalk-shaped impressed decoration, also called "false acacia leaf" (Ferreira, 1970; Nukushina, 2015; Simões, 1999).

In archeological sites related to this period, such as Abrigo Grande das Bocas and Gruta da Senhora da Luz (Rio Maior), São Pedro de Canaferrim (Sintra), Gruta da Furninha (Peniche), and Carrascal (Oeiras), we find pottery collections with an unarguable decorative homogeneity (Cardoso, 2015; Cardoso, Carreira, \& Ferreira, 1996; Carreira, 1994; Diniz, 1994; Simões, 1999). Such patterns and techniques (impression prevailing over incision and plastic decoration) converge toward a clearly regional phenomenon, in this case of the Portuguese Estremadura, since they are found throughout this entire territory (Diniz, 2007, p. 208).

In North of Estremadura, more specifically in its Limestone Massif, we can see a significant number of sites with pottery collections showing the aforementioned features. Decorative themes found in most decorated vessels from Forno do Terreirinho, Laranjal do Cabeço das Pias, and Abrigo da Pena d'Água (Carvalho, 2007) reinforce this idea of cultural consistency within a well-defined space.

Regarding the same timeframe, to the Southeast of Estremadura, in Inland Alentejo, available data come exclusively from the settlements of Valada do Mato (Évora) and Patalim (Montemor-o-Novo) - clearly 
showing the archeographic limitations that persist in this territory and timeframe. Here, we find what may be considered another cultural regionalism, which in the case of pottery vessels is based on a decorative scheme marked by "... the impression of different wide-band matrixes and sequences of incised lines or fluting, in both cases running parallel to the rim” (Diniz, 2007, p. 209), mostly with circular handles (Diniz, 2003, p. 38; Ferreira, 2005). In this region, contrasting with the Portuguese Estremadura, there is a decreased use of ear of "false acacia leaf," as well as of incised bands filled with incised diagonal lines. Bifid handles have not been found until today.

In the interface between these two territories and social units (Portuguese Estremadura and Inland Alentejo), and regarding the same time span, there are domestic contexts in which pottery collections show mixed elements, with decorative patterns clearly associated with Inland Alentejo and elements mostly identified with Estremadura (Figure 2).

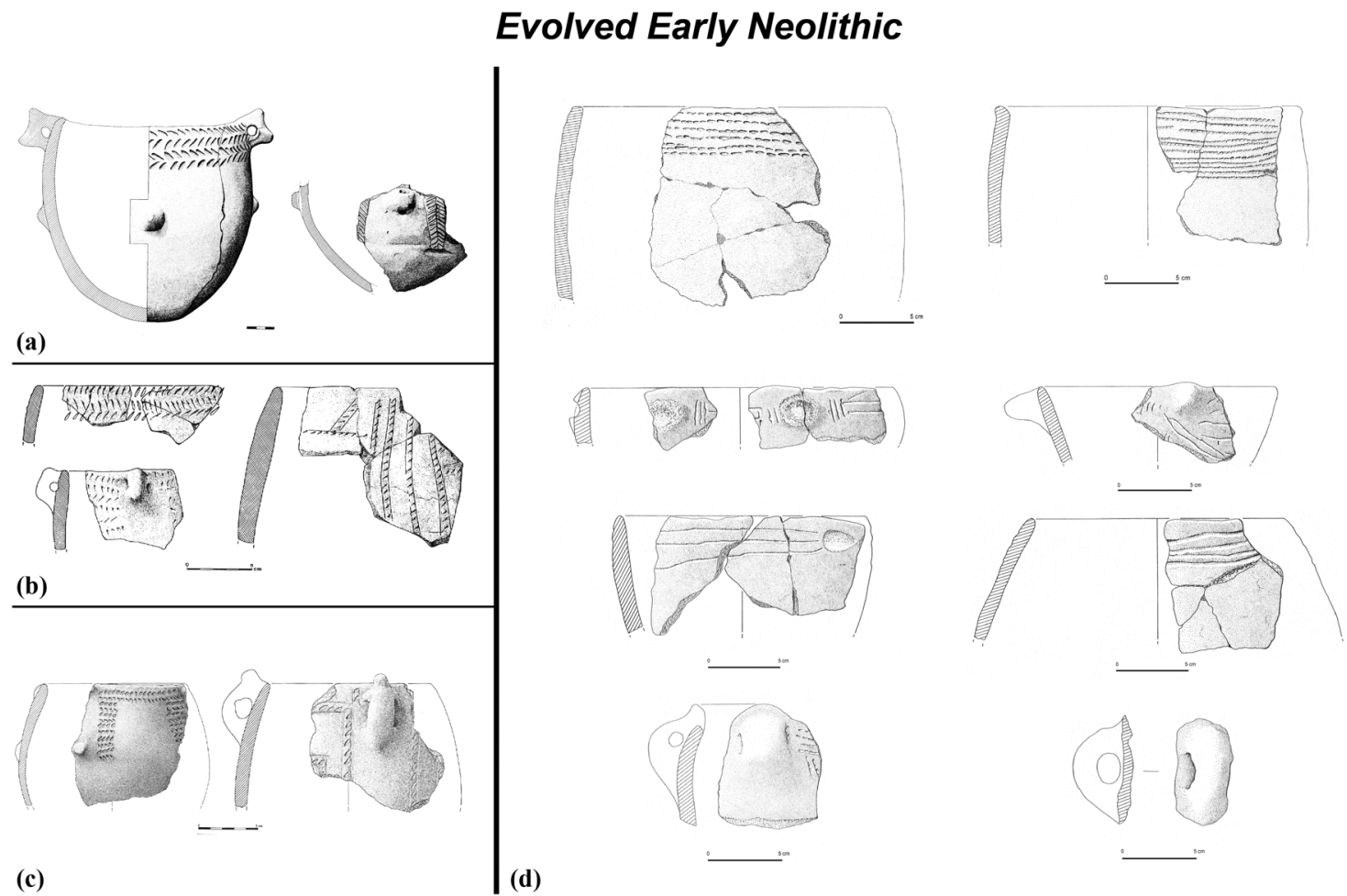

Figure 2: Evolved Early Neolithic ( $5200-4500$ cal BC): pottery decoration. (a) Senhora da Luz (Estremadura region); (b) Abrigo Grande das Bocas (Estremadura region); (c) São Pedro de Canaferrim (Estremadura region); (d) Valada do Mato (Inland Alentejo). Adapted from: Cardoso et al., (1996), Carreira (1994), Simões (1999), and Diniz (2007).

The site of Casal da Cerca (Palmela) is a fine example of this analysis. Its artifacts form a fusion pottery collection, in which decorated pottery shows decorative grammars representative of both Estremadura contexts - i.e., incised bands filled with short diagonal impressions and "false acacia leaf" decoration - and Alentejo contexts - i.e., circular handles and sequences of incised lines parallel to the rim (Silva \& Soares, 2014, p. 93, 94). Thus, Casal da Cerca demonstrates that, although certain decorative patterns have clear regional identities, the collections are not hermetic, and in interface areas, pottery collections include decorative patterns from different provenances.

In addition to the specificity and regional character of decorative grammars, this evolved moment of the Early Neolithic is characterized by an outstanding presence of decorated vessels over undecorated vessels in the archeological record insofar as pottery is concerned. A comparative analysis of the statistical data of a radiocarbon dated site, belonging to each of the geographical areas mentioned earlier, found that decorated vessels clearly prevailed over undecorated vessels. 
In Estremadura, the pottery sample from São Pedro de Canaferrim includes $86 \%$ of decorated vessels versus only $14 \%$ of undecorated vessels. At Valada do Mato (Inland Alentejo), the unbalance is not so obvious, but it remains eloquent. In this case, decorated vessels represented $69 \%$ of the analyzed sample versus only $31 \%$ of undecorated elements. At Casal da Cerca, decorated vessels still prevailed, representing $60 \%$ of the set versus only $40 \%$ of undecorated ones.

If we add to this picture the Early Neolithic occupation data from Carrascal (Oeiras - Portuguese Estremadura), while taking in account that only the data from the first excavation campaign have been considered and published (Cardoso, Silva, \& Soares, 2008), we find very similar statistical results, with decorated vessels representing $63 \%$ of pottery artefacts and undecorated vessels representing the remaining $37 \%$.

In chronological terms, the aforementioned interpretations cover a timeframe ranging from the last quarter of the 6th millennium and the early 5th millennium cal BC $(\sim 5200-4800 \mathrm{cal} B C)$, taking into account the absolute dates established for these three: unequivocally, synchronous, and occupations (Diniz, 2001; Silva \& Soares, 2014; Simões, 2003) (Figures 3 and 4).

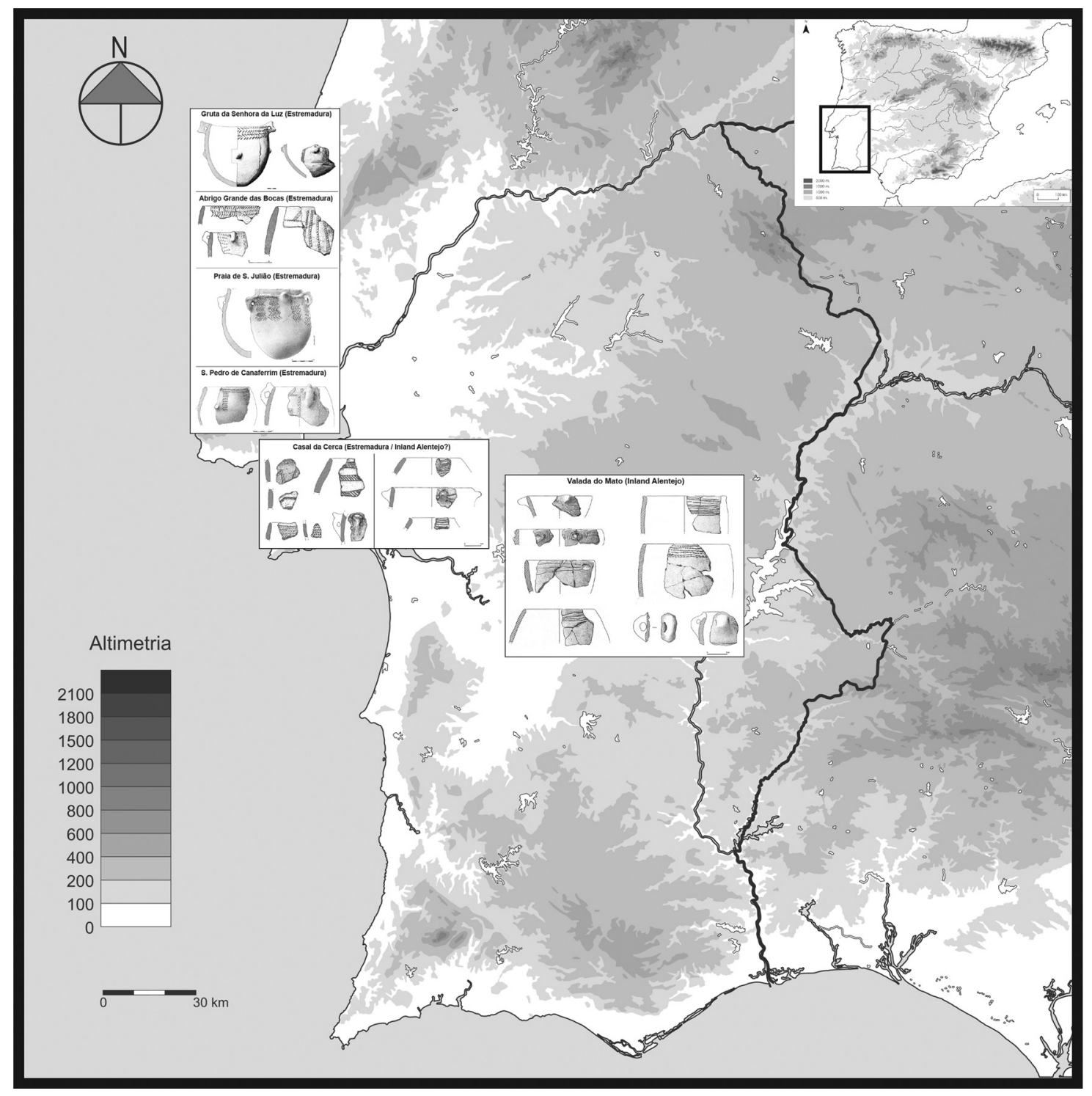

Figure 3: Evolved Early Neolithic. Pottery decoration systems distribution (according to: Cardoso et al., 1996; Carreira, 1994; Diniz, 2007; Silva \& Soares, 2014; Simões, 1999; basemap: Boaventura, 2009; Trabajos de Prehistoria for the map of Iberia). 


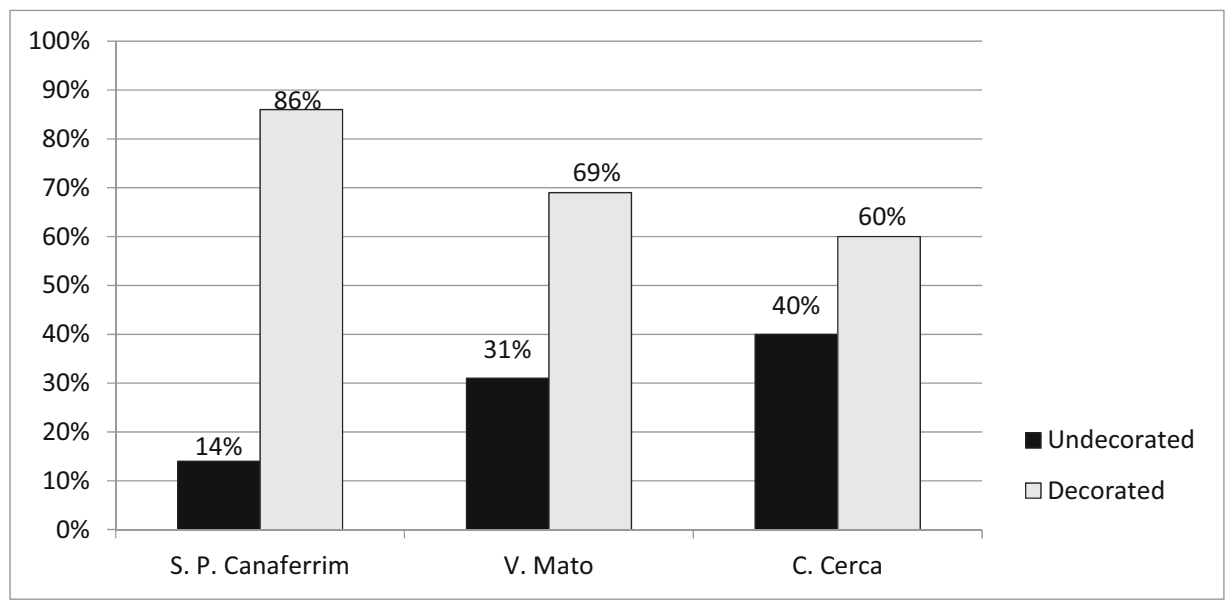

Figure 4: Evolved Early Neolithic. Undecorated versus decorated pottery (according to Diniz, 2007; Silva \& Soares, 2014; Simões, 1999).

Three key traits can be identified for the late Early Neolithic ( 5200-4500 cal BC): (a) decorative diversity, illustrated by pottery vessels, which may reflect identity marks and social differences among groups inhabiting different geographical areas; (b) prevailing use of the impression technique; and (c) prevalence of decorated vessels over undecorated vessels.

As shown later, this outlook will change during the transition to the Middle Neolithic.

\subsection{Initial Middle Neolithic (4500-3700 cal BC)}

Transition from the final phase of the Early Neolithic to the Middle Neolithic occurred from 4500 cal BC onward involving a set of complex cultural changes that has not yet been fully assessed (Carvalho, 2014; Mataloto \& Boaventura, 2009; Neves, 2018; Neves \& Diniz, 2014).

Material culture underwent deep changes, namely, in terms of pottery production - one of the best diagnostic factors for this new period. We adopted exclusively typological criteria, since radiometric data are still scarce and do not cover part of the territory where the presence of these groups is becoming evident.

Consequently, and as far as decorative themes are concerned, pottery decorated with incised line below the rim seems to characterize a transformation stage between a period of abundantly decorated pottery, as shown earlier, in the early stages of the Neolithisation process, and the production of totally undecorated vessels, which clearly prevailed in the Middle Neolithic (Carvalho, 1998, p. 64; Diniz \& Neves, 2018, p. 533; Neves, 2010, 2015a, 2018; Silva \& Soares, 1980, p. 15; Soares \& Silva, 2013, p. 158).

Vessels decorated with incised line below the rim were already part of the decorative grammar of certain artifact collections of the previous period, although in a much smaller percentage - e.g., at Casal da Cerca and Vale Marim II (Sines, Southwest Coast), chronometrically dated from the late 6th millennium to the early 5th millennium cal BC (Silva \& Soares, 2014, p. 93; Silva, Soares, \& Coelho-Soares, 2010, p. 14). The number and significance of such decorative motif increased after $4500 \mathrm{cal} \mathrm{BC}$ during the transition from the Early Neolithic to the Initial Middle Neolithic in Western Iberia (Diniz, 2000; Neves, 2018; Neves \& Diniz, 2014).

This decorative motif, using the incision technique, is part of a set of changes found in material culture, which became more significant at this transition stage. The changes of social contexts that gave rise to such transformation are yet to be determined.

Regarding the Initial Middle Neolithic pottery collections, the incised line below the rim motif is the dominant decorative element. It was used in vessels with different shapes and found in collections of mostly undecorated vessels. The impression technique is merely residual as opposed to incision - now the most used technique in the increasingly less recurrent act of decoration (Figure 5). 
Initial Middle Neolithic
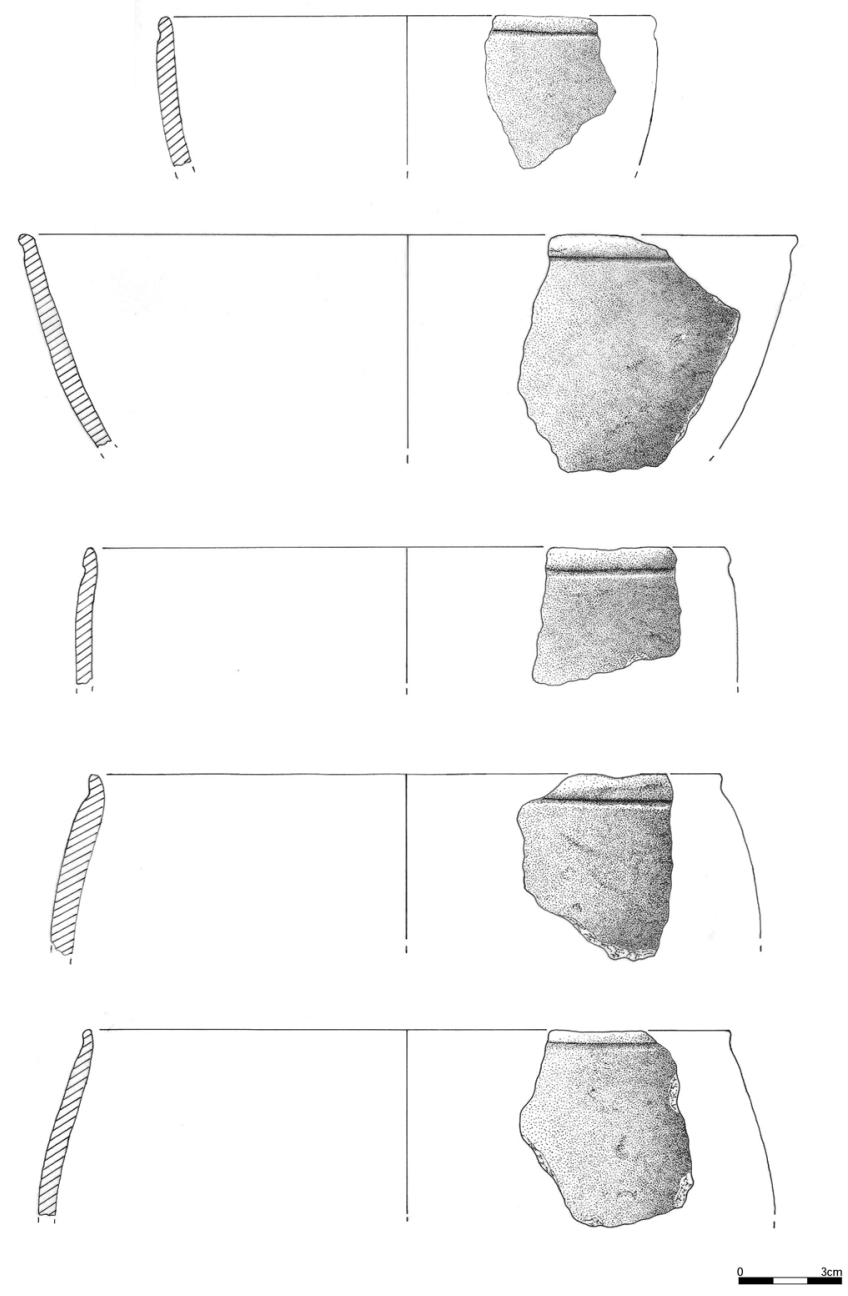

Figure 5: Evolved Early Neolithic ( 4500-3700 cal BC): Line below the rim from Monte da Foz (adapted from: Neves, 2010).

Decoration with incised line below the rim was first identified, and thus named, by C.T. da Silva and J. Soares, during their research on the Early Neolithic communities in Portugal's Southwest Coast (Silva \& Soares, 1980, 1981). At that time, it was considered as evidencing a possible "regionalism" or indication of a "cultural identity" related to that specific region. However, the evolution of archeological research showed that the exclusive presence of incised line below the rim decoration in Southwest Coast contexts reflected an archeographic bias, resulting from a specific phase of the history of research. According to currently available data, its "distribution" is much wider, occurring in different geographies. It has been recorded in a significant number of habitat sites, ranging from the northern area of Portuguese Estremadura to the Lower Basin of the Tagus, and further south, reaching Inland Alentejo, the Southwest Coast, and finally the Algarve (Neves, 2010, 2015a, 2015b, 2018).

Even though this article only analyzes the Early-Middle Neolithic transition in the Portuguese territory, it should be clear that the presence of this decorative pattern at the early stages of Middle Neolithic is not exclusive of "Portuguese" contexts. In Andalucía (SW Spain), ceramic vessels decorated with incised line below the rim have been found in the vicinity of Málaga - at Cueva de Nerja: sala de la Mina - Huelva - Arroyo de Santa María - and Jaén - Grañena Baja. In this region, they also dated from the early stages of Middle Neolithic of the so-called Andaluzian Neolithic (García Borja et al., 2014; Vera Rodríguez \& Martínez Fernández, in press; Conlin Hayes, Martínez Sánchez, \& Morgado, 2020). 
In an attempt to empirically validate our interpretation of pottery productions in the Initial Middle Neolithic ( 4500-3700 cal BC), we resorted to the same comparative exercise applied to the previous period, analyzing the available data from three domestic occupations related to the same chrono-cultural frame from three different geographies, i.e., Portuguese Estremadura, Left Bank of the Lower Tagus Valley, and Southwest Coast. This analysis not only bears witness to the wide geographical distribution of the incised line below the rim decoration but also evidences its dominance in the universe of decorated pottery. Furthermore, it also quantifies a trend that would become clearer in the Full Moment of the Middle Neolithic, i.e., the prevalence of fully undecorated vessels over decorated ones.

In the Portuguese Estremadura, undecorated vessels prevail in the pottery sample from the Db layer of the Initial Middle Neolithic collected at Pena d'Água (Torres Novas) (Carvalho, 1998), totaling 92\% of the collection. The remaining $8 \%$ are decorated. Of this small sample, $67 \%$ (4 items) are vessels decorated with incised line below the rim.

Across the river Tagus, on its left bank, we find the occupation of Monte da Foz 1 (Benavente), where $76 \%$ of the pottery collection consists of fully undecorated vessels, against $24 \%$ of decorated ones (Neves, 2010). In this occupation, the share of vessels decorated with incised line below the rim rises to 68\% (39 items). This value is statistically identical to the one found in the Db layer of Pena d'Água.

Further south, at the site of Palmeirinha (Sines, Southwest Coast), we can verify the trend observed in other two occupations (Silva et al., 2010). The analyzed sample underlined, once more, the strong weight of undecorated pottery (85\%) versus decorated pottery (15\%). Vessels decorated with incised line below the rim are still the most represented ( $82 \%-14$ items).

As the incised line below the rim becomes the only standard and recurrent motif in decorated pottery vessels, the greatest difficulty is to date it accurately.

As in other stages of the Middle Neolithic in Western Iberia, this initial period is also marked by a very small number of dated contexts - namely, those in which pottery with incised line below the rim decoration is well represented - in a universe already dominated by undecorated ceramics.

Moreover, the dated sites that fit these categories either have not yet been fully studied or the available data regarding the number of pottery production is not clear or even insufficient.

The only item with incised line below the rim decoration identified in the region of the Algarve (southern Portugal) was found at the site of Algarão da Goldra (Faro). Here, a series of radiocarbon dates obtained from human remains suggests the cave was used between 4500 and $4000 \mathrm{cal} \mathrm{BC}$. Therefore, it bears witness to the beginning of Middle Neolithic in this region (Carvalho \& Straus, 2013).

In Inland Alentejo, a set totally composed of undecorated pottery was collected at an occupation previous to the megalithic monument of Vale Rodrigo 3 (Évora). It included items of pottery with incised line below the rim decoration, and it was dated from 3938 to 3699 cal BC (Armbruester, 2008, p. 86). Also, in this region, it was recovered a high number of elements with this decorative motif in the domestic sites of Alminho (Ponte de Sor), in the preview occupation of the funerary megalithic monument of Hortinha (Évora), and Fábrica da Celulose (Mourão). Unfortunately, without available radiocarbon dates (Deus, 2008; Rocha, 2007; Silva \& Soares, 2018).

In the Southwest Coast, in the Comporta area, a strong presence of pottery with incised line below the rim decoration, associated with a scarce ensemble of decorated items, was found at the site of Pontal, which was frequently mentioned in the scientific literature, albeit with a poor identification of all the components included in its artifact package. According to the authors, it represents a "...decoration that closes the cycle of impressed/incised pottery of the Evolved Neolithic in Coastal Alentejo” (Soares \& Silva, 2013, p. 158). A clam sample enabled to date this site from a time bracket between 3904 and 3638 cal BC (Soares \& Silva, 2013, p. 154). Also in the Southwest Coast, near mentioned Palmeirinha site, there are data on the open-air site of Brejo Redondo, where the presence of pottery with incised line below the rim gets $50 \%$ of the decorated set, which is only $29 \%$ of the total pottery assemblage, following the cultural behavior recognized for this moment (Silva \& Soares, 2004). In Portuguese Estremadura, the site of Costa do Pereiro (Torres Novas) the scarce available data points, as observed at Monte da Foz 1, to an unequivocal representation of undecorated pottery and vessels with incised line below the rim (Nunes \& Carvalho, 2013, p. 330). A human 
burial context associated with the domestic occupation is dated from 4040 to $3795 \mathrm{cal}$ BC (Carvalho \& Petchey, 2013, p. 365).

Based on the available absolute dates associated with archeological contexts, marked by a strong presence of vessels decorated with incised line below the rim, the transition to the Initial Middle Neolithic in Western Iberia began in the third quarter of the 5th millennium cal BC. Specificities evidenced by pottery productions that characterize this transition phase are more obvious in the first quarter of the 4 th millennium, thus establishing a long interval for this moment from 4500 to $3700 \mathrm{cal} B C$.

The presence of this decorative motif in such a wide geography, together with sets dominated by undecorated vessels, may suggest an Initial Middle Neolithic marked by highly mobile human communities, available to interact and connect with other groups that occupy a vast territory, increasingly unified in socio-cultural terms (Figures 6 and 7).

This mobility and interaction resulted in a highly homogeneous archeological record, in terms of pottery production, in a deep contrast with the stylistic and thematic variety that characterized the late stages of the Early Neolithic.

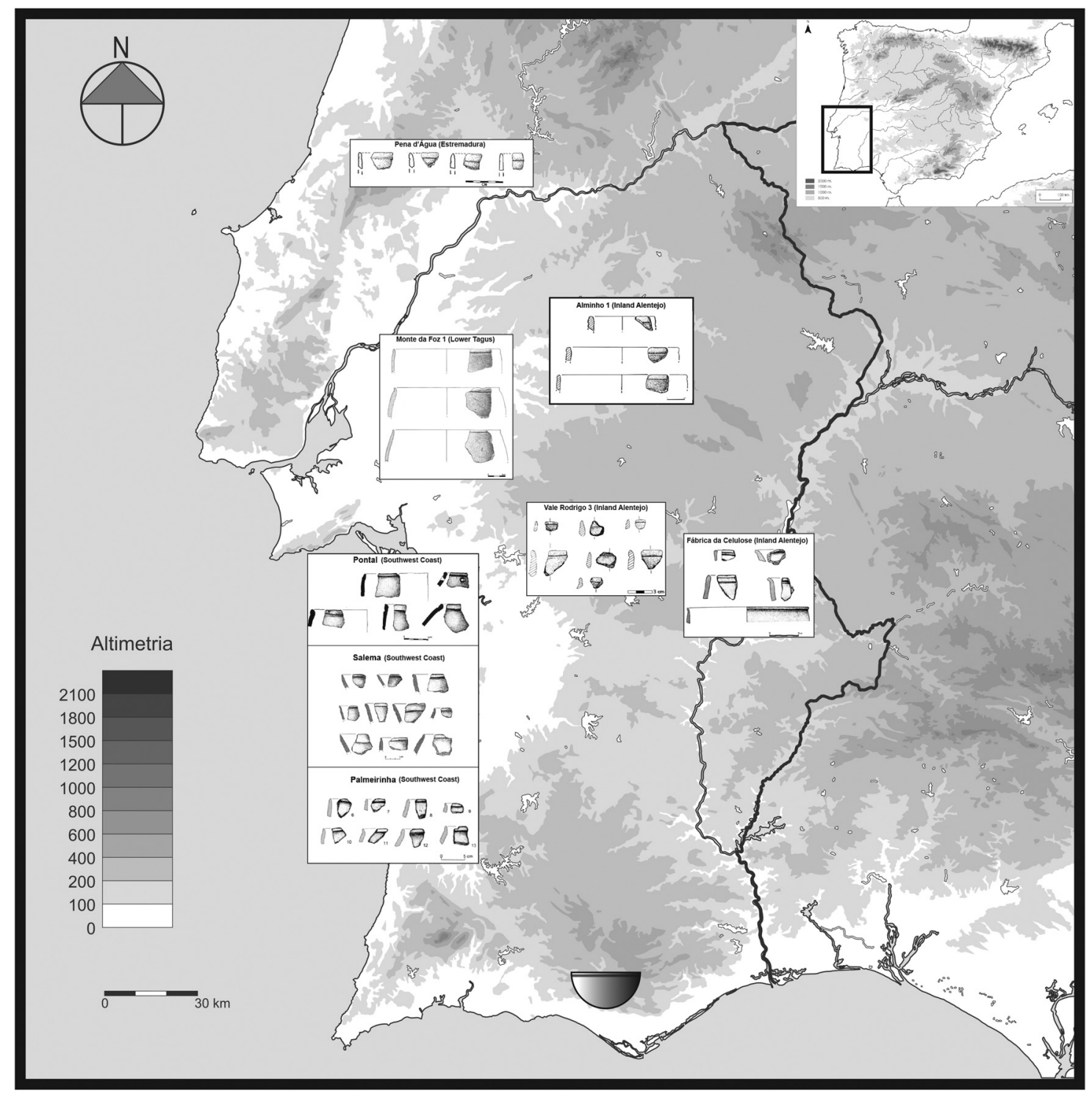

Figure 6: Initial Middle Neolithic. Pottery decoration systems distribution - incised line below the rim (according to: Armbruester, 2006; Carvalho, 1998; Deus, 2008; Neves, 2010; Silva \& Soares, 1981, 2018; Silva et al., 2010; Silva \& Soares, 1980; basemap: Boaventura, 2009; Trabajos de Prehistoria for the map of Iberia). 


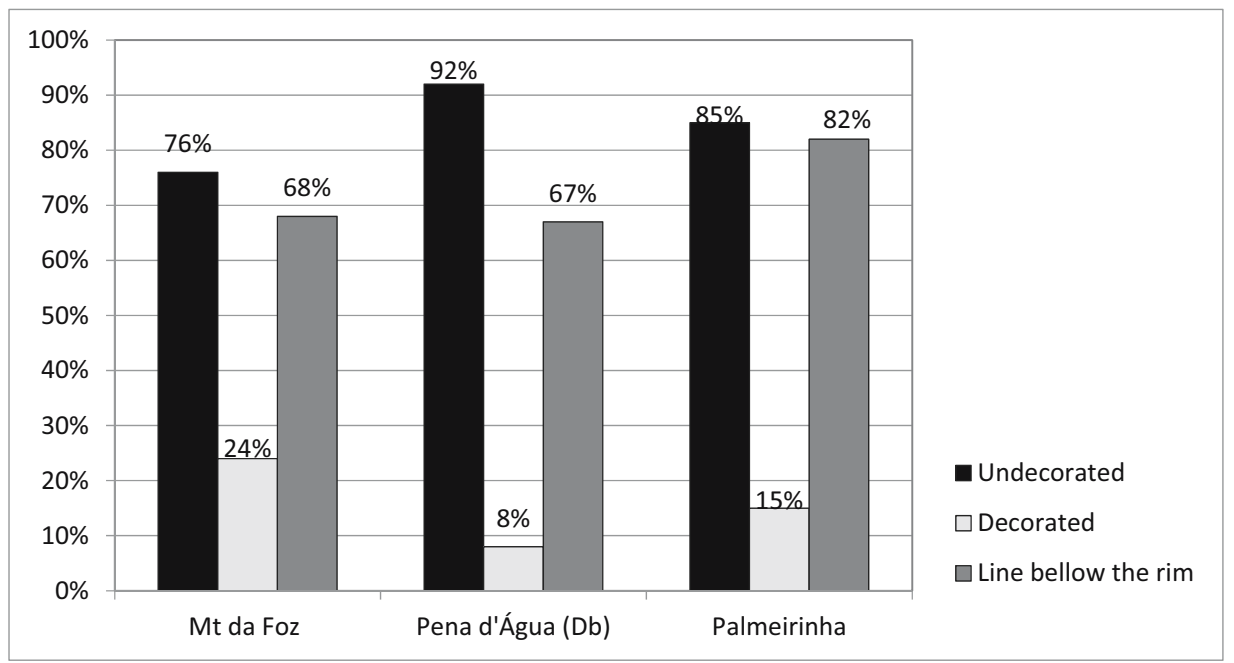

Figure 7: Initial Middle Neolithic. Undecorated versus decorated pottery and the percentage presence of decorated vessels with an incised line below the rim (according to Carvalho, 2016; Neves, 2010; Silva et al., 2010).

\subsection{Full Moment of the Middle Neolithic (3700-3200 cal BC)}

The "cycle of undecorated pottery" developed amidst this strong circulation dynamics among different regional spaces. It is also connected to the next phase: the Full Moment of the Middle Neolithic.

Only a small number of domestic sites clearly related with this moment have yet been found in Western Iberia. The lack of "guiding fossils" in the material culture - e.g., decorative motifs in pottery, prehension elements and/or plastic decoration, carinated vessels, and arrowheads in lithic industries - renders the identification of contexts quite difficult. This justifies the poorer knowledge we have of this period, which seems to have developed around the mid-4th millennium, from 3700 to $3300 \mathrm{cal}$ BC (Neves, 2018).

As observed for the Initial Middle Neolithic, the available data are also unbalanced, not allowing for comparative analyses and broader-scale interpretations. We face the absence of absolute dates for some known occupations that have already been studied, while other contexts with absolute chronology of this period do not provide full data regarding their material culture or do not evidence the selection criteria for the analyzed and published sample.

The settlement contexts dated from the Full Moment of the Middle Neolithic present totally undecorated pottery collections. However, in some cases, we do find decorated patterns, usually incised, albeit highly residual and with no percentual relevance (Figure 8).

This narrative is clearly backed up by three habitat sites located in the three regional areas mentioned earlier, i.e., Pena d'Água (Portuguese Estremadura), Moita do Ourives - (Lower Tagus Valley), and Barrosinha - Southwest Coast (Carvalho, 2016; Neves, 2018; Soares \& Silva, 2013).

The number of decorated sherds does not exceed 7\% in the Da layer of Pena d'Água, corresponding to the Middle Neolithic. At Moita do Ourives, six decorated fragments (using the incision technique) have been recorded, representing only $2 \%$ of the total sample. Further South, in the occupation identified in layer 4 of Barrosinha, a completely undecorated pottery collection was found - except for a single piece decorated with incised line below the rim, thus making decorated pottery represent approximately $1 \%$.

This occupation level of Barrosinha has two absolute dates, ranging from 3761 to 3373 cal BC (Soares \& Silva, 2013, p. 154) - a timeframe very similar to the one found at the Middle Neolithic occupation of Senhora da Alegria (Coimbra). At this site, composed of several lines of ditches, located further north of the geographical area studied in this article, a hearth "associated with a material culture characterized by totally undecorated pottery, shaped as spheres" (Valera, 2013, p. 338) yielded a timeframe ranging from 3636 to $3376 \mathrm{cal} \mathrm{BC}$. So far, it has not been possible to analyze the material culture of this occupation since is still being studied by its scientific supervisors. 


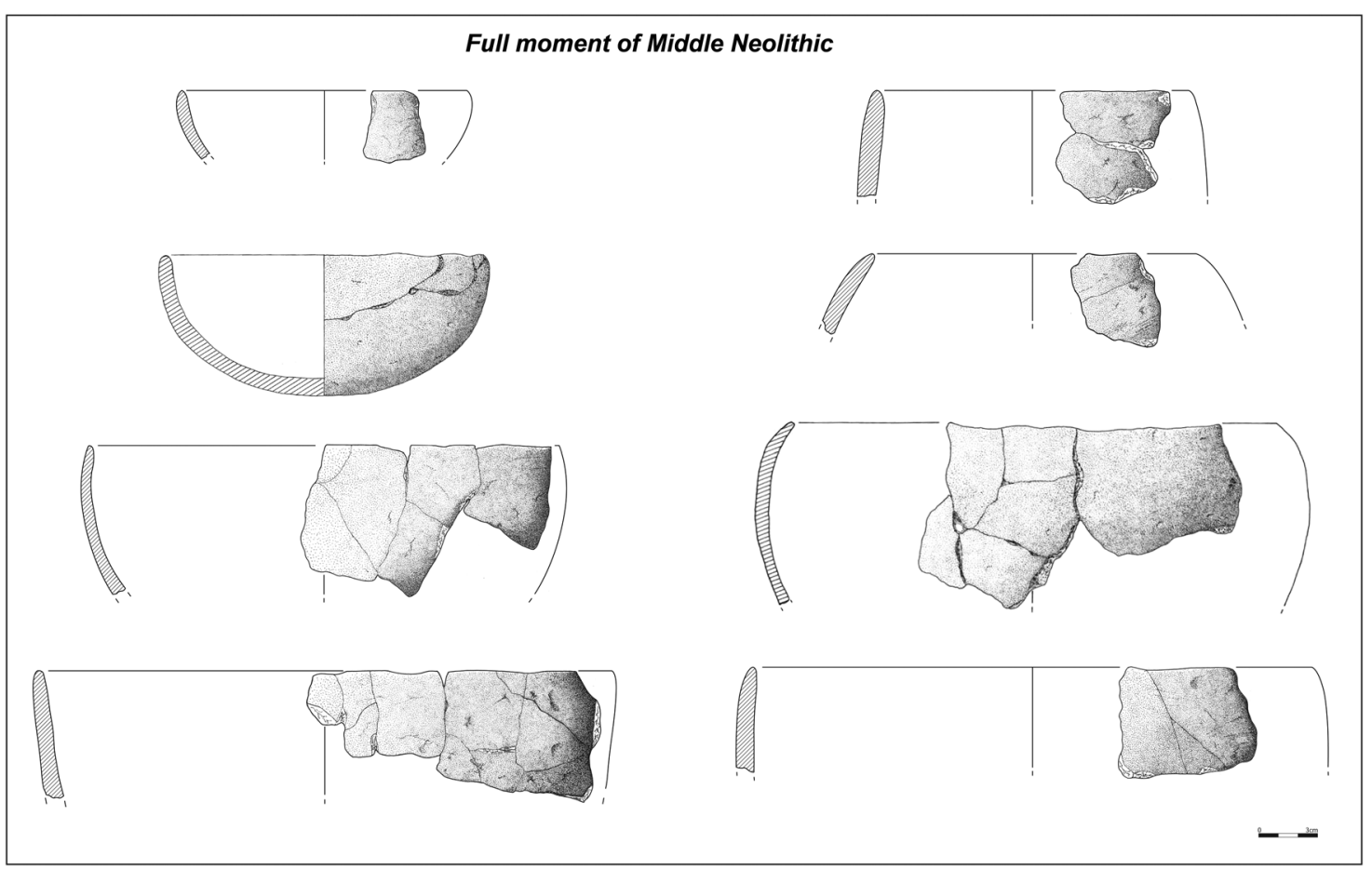

Figure 8: Full Moment of Middle Neolithic ( 3700-3300 cal BC): Pottery from Moita do Ourives (accordind to: Neves, 2018).

Considering its timeframe, the available indicators of its artifact collection, and its location, we can envision that these undecorated pottery sets were broadly disseminated at a time that clearly match with the dispersion and expansion of the funerary Megalithic culture in Western Iberia (Figures 9 and 10).

\section{Discussion}

\subsection{Pottery, Material Culture, and the Chrono-Cultural Transition From the Early Neolithic to the Middle Neolithic: An Overview Analysis}

Following our analysis of pottery assemblages record in domestic sites, from the final phase of the Early Neolithic to the Full Moment of the Middle Neolithic in Western Iberia, we have tried to contribute to the definition of this chrono-cultural transition, which strongly impacted on social, symbolic, and, on a different scale, economic behaviors (Table 1 and Figure 11).

So, pottery presents itself as an indicator of temporal, spatial, and social variability but, above all, as a clear chrono-cultural marker in the Neolithisation process. Through its full accounting and analysis of the statistical weight, namely, in terms of the presence and absence of decorative elements, it is possible to trace an evolutionary record that starts at the end of the Early Neolithic, from the late 6th millennium, ending with the Full Moment of Middle Neolithic, already in the middle of the 4th millennium.

For now, we can establish the following sequence:

\subsection{1 $\sim 5200-4500$ cal BC}

Most pottery set are decorated, evidencing the strong social weight given to decorative grammars. 


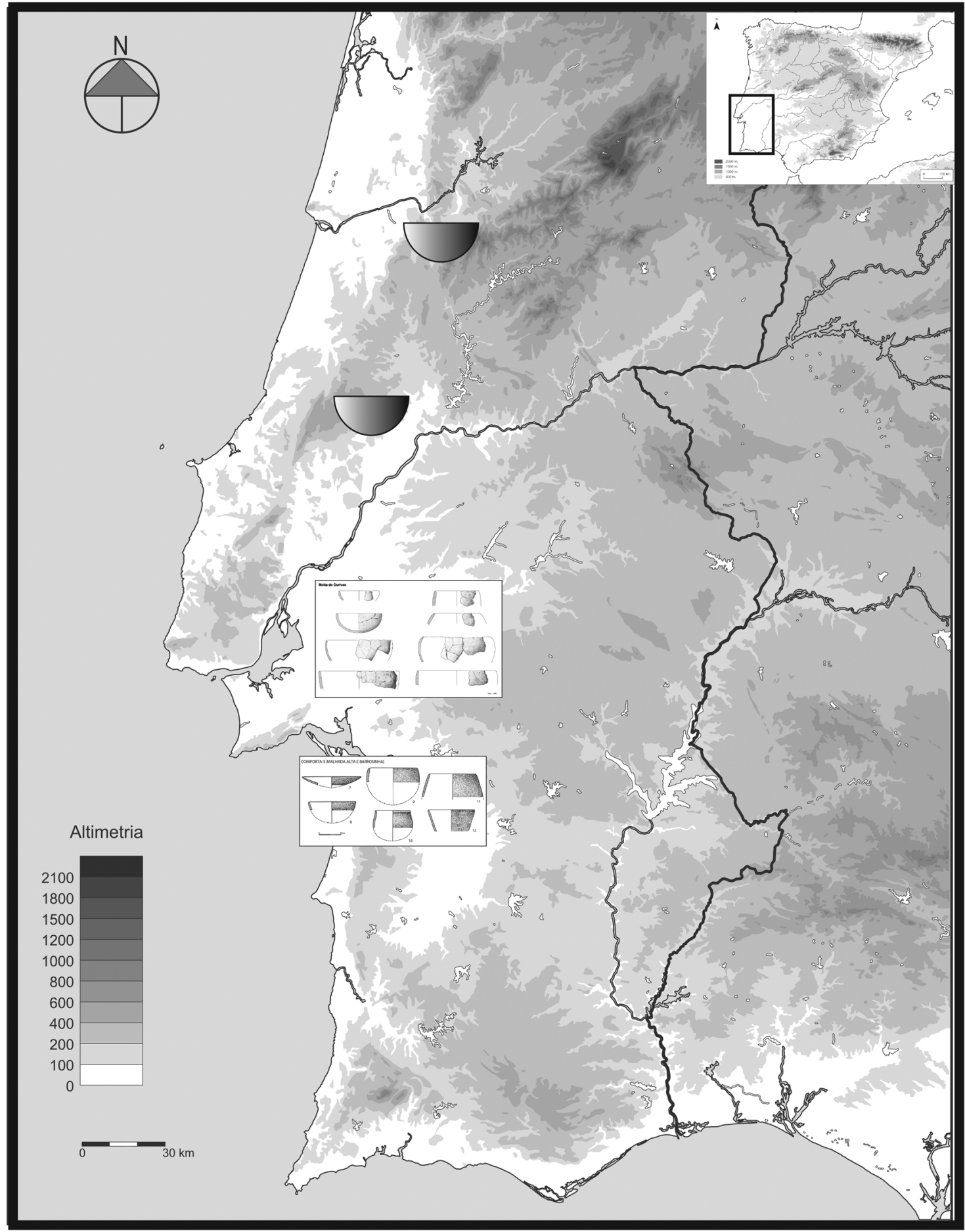

Figure 9: Full Moment of the Middle Neolithic ( 3700-3300 cal BC): Pottery decoration systems distribution (according to: Carvalho, 2016; Neves, 2018; Soares \& Silva, 2013; Valera, 2013; basemap: Boaventura, 2009; Trabajos de Prehistoria for the map of Iberia).

Judging from samples found at different habitat spaces, the number of decorated vessels (especially by impression) is clearly dominant. In addition to this feature, and as far as pottery production is concerned, this period - the Evolved Early Neolithic - is marked by the diversity of decorative motifs, which mirror the identity of the region where they are produced, evidencing a multiform cultural landscape. 


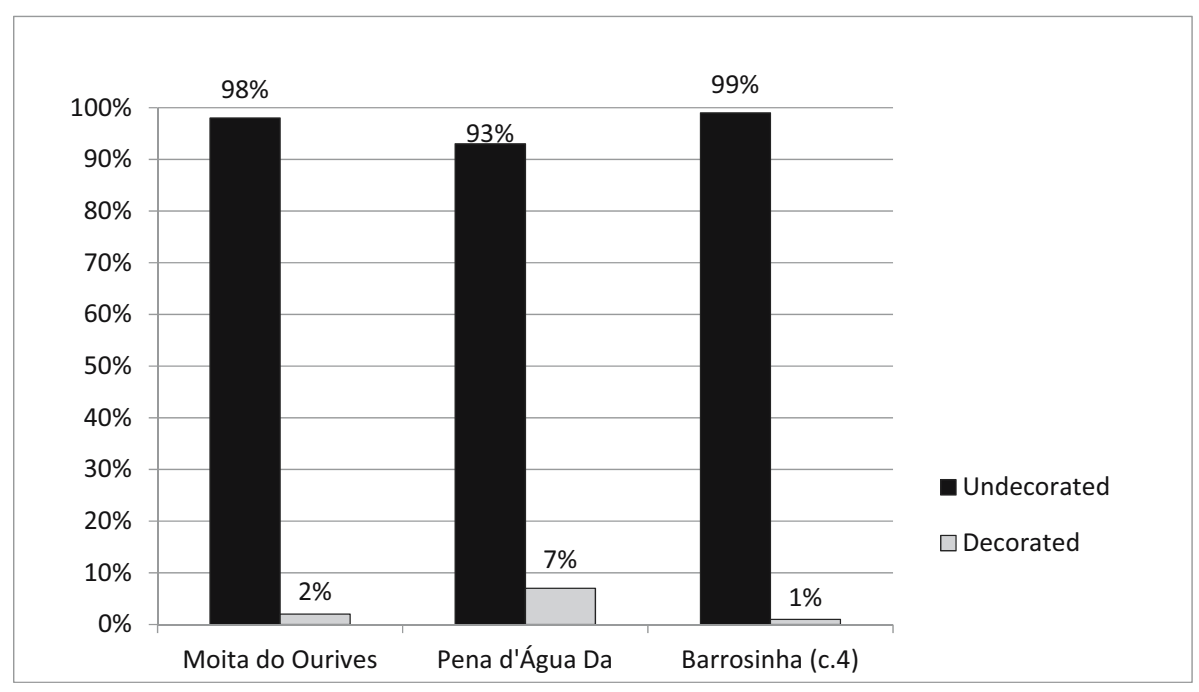

Figure 10: Full Moment of the Middle Neolithic ( 3700-3300 cal BC): undecorated versus decorated pottery (according to: Carvalho, 2016; Neves, 2018; Soares \& Silva, 2013).

Therefore, we can identify and quantify a given decorative pattern or motif and associate it with a specific regional space. This interpretation was possible for the regions of Portuguese Estremadura and Inland Alentejo. Regarding this phase of the Neolithisation process, we can suggest the existence of regionalisms and sociocultural identities in groups that occupy a vast territory and evolve in parallel lines, notwithstanding the cultural distance suggested by decorative themes.

As Claire Manen observed for the initial Early Neolithic in the area between the Rhone and the Ebro, there are a multiform pottery styles - a thematic diversity that possibly points at the different origins of Neolithic groups - where two pottery ensembles, with markedly different attributes, hint a clear cultural difference, singling out different communities in a wider landscape (Manen, 2002, p. 131).

To some extent, this interpretation apparently has a few parallels in some results yielded by ethnoarcheological studies, which seek to identify perennial features in contemporary tribal societies. We recognize that the use of modern Ethnography in a prehistoric analysis could have limitations. However, it can be useful to approach and understand the social mechanisms underlying the Neolithic European and Near Eastern societies.

Analyzing pottery made by the Gzaua tribe (Morocco), it was possible to observe that decorated pottery (in this case, painted) has different meanings in terms of identity (tribal, local, and individual). Similar to what we observed in the evolved phase of the Early Neolithic in Western Iberia, "the decorations of each tribe have specific attributes that enable us to identify their origin.” (Urquijo, Estévez, Peña, \& Chocarro, 2001, p. 20).

\subsubsection{0-3700 cal BC}

In the transition to the Middle Neolithic, especially in its initial phase, the social weight of decorative grammars in pottery seems to reduce significantly. This decrease of decorated pottery and the disappearance of prehension and suspension elements - i.e. handles, nipples, and ribbons - were recorded in a vast territory (Central and Southern regions of Western Iberia). They are part of a set of changes observed in Material Culture, also detected in flaked stone industries (Neves, 2018). Diversity, expressed through material culture in the late Early Neolithic, seems to be replaced by artefactual uniformity in the Middle Neolithic.

As regards pottery, apart from the growing importance of undecorated vessels, decorative systems survive in the recurrent application of the incision technique, to the detriment of impression (which 


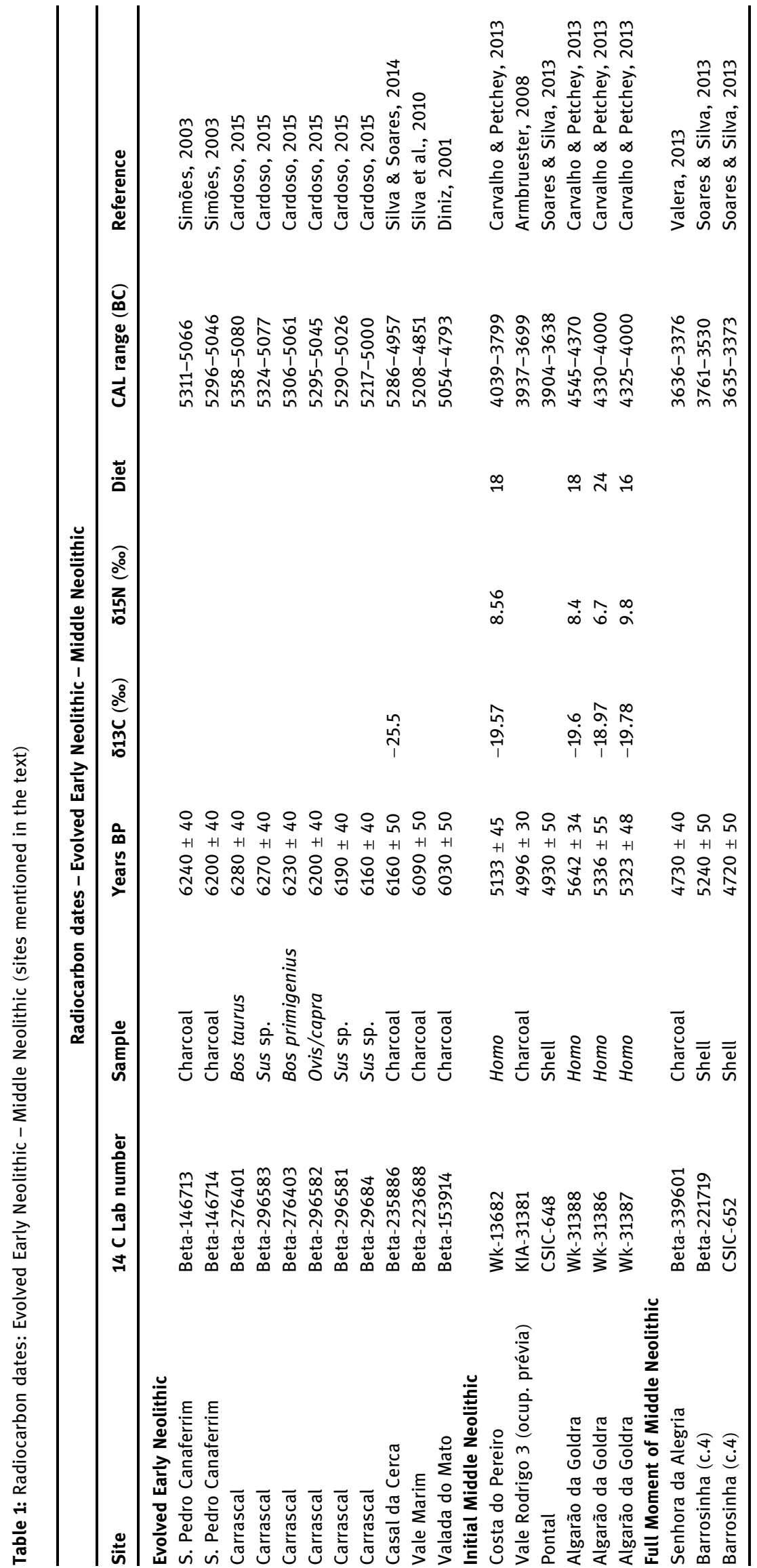




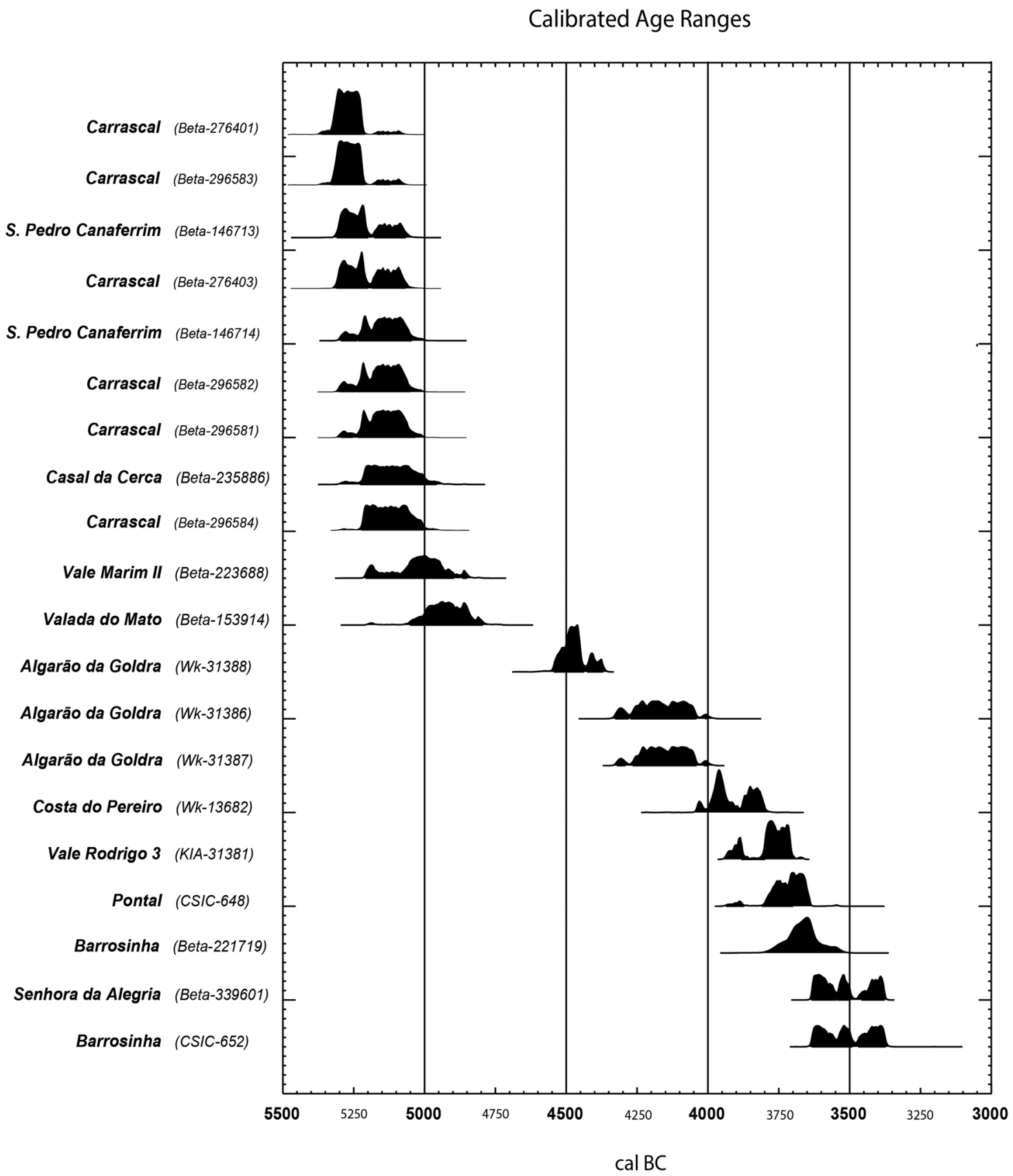

Figure 11: Radiocarbon dates available for domestic sites of Evolved Early Neolithic - Middle Neolithic mention in the text. Calibrated with IntCal13 atmospheric curve (Reimer et al., 2013).

prevailed in the first stage), and a single motif, i.e., the incised line below the rim. This type of decoration prevails among decorated pottery of this period and is found in several regional contexts. This strengthens the interpretation according to which artifact collections seem to be identical in all occupations of the late Early Neolithic and the Initial Middle Neolithic.

As mentioned earlier, this Material Cultural uniformity and the presence of the incised line below the rim in multiple regional contexts demonstrate that the Initial Middle Neolithic is characterized by the existence of communities that frequently circulate and interact, occupying a vast area of Western Iberia. This could be a stage marked by cultural homogeneity, meaning that, at this stage, the Neolithisation process develops as a more consistent whole from the social, cultural, and economic points of view. 
This phenomenon, marked by stylistic homogeneity in pottery decoration in an increasingly larger territory, as opposed to the previous stage, had already taken place in Phase III, as defined by Manen for Northeast Iberia. In this region, between 5000 and $4500 \mathrm{cal} \mathrm{BC}$, stylistic thematic associated with the Recent Epicardial moment (prevalence of incisions and absence of impression) homogeneously spread to the entire region under study (Languedoc and Catalonia), also reaching the regions of Valencia and Andalucía (Manen, 2002, p. 157). For this area, this moment of consolidation and increasing homogeneity began, at least, around 500 years before it occurred in the current Portuguese territory. "La céramique présente des formes et des décors qui annoncent la transition vers le Néolithique moyen, c'est-à-dire vers les horizons à poterie lisse.” (Manen, 2002, p. 157), as seemed to be the case in Western Iberia.

\subsubsection{0-3200 cal BC}

In the Full Moment of Middle Neolithic, side by side with the beginning of the funerary Megalithism (Boaventura, 2009), pottery evidences an almost total absence of decorative grammars. Pottery sets become markedly "common" and have a reduced "discourse power." Undecorated pottery becomes even more present, sometimes totally prevailing, than in the immediately previous period.

Even though few contexts have been studied so far, this was plausibly the reality found in a vast geographical area, following a line of evolution that seemingly began in of the late Early Neolithic.

Chronologically speaking, the available data appear to point at a time bracket ranging from the 2nd to the 3rd quarter of the 4th millennium cal BC.

\section{5 (A First) Synthesis}

Although research on the empirical data available for the transition between the Early Neolithic and Middle Neolithic has clearly evolved, we are aware that a study of this nature is far from finished.

As we consider the changes occurred as from the Initial Middle Neolithic ( $4500 \mathrm{cal} B C)$, it is important to define their economic, social, and symbolic meaning as regards pottery production. These are related to the significant decrease of decorated vessels, and their eventual disappearance, as well the existence of a single and recurrent decorative motif in the scarce examples of decorated pottery (i.e., incised line below the rim).

Also, reference should be made to the fact that most-known settlement occupations available for analysis correspond to a certain occupational strategy and economic subsystem (short-duration temporary habitats). Did this model of pottery production define the network of settlements in this entire chronocultural space? Or was it just one model of occupation and functional typology? Do the elements of the pottery collections herein analyzed define a certain functional typology of habitat, a strategy of occupation, and an economic subsystem, or do they effectively represent the pottery production of this entire moment?

If we want to answer these questions, we must have a broader empirical evidence and enlarge the scientific questionnaire concerning the material culture features of these occupations. The study of pottery collections does not end with the interpretations presented in this article, and other fields of analysis need to be explored. Discourses emerging from studies of these collections indisputably have a strong technicaltechnological component, and now we need a new and broader grid of analysis that includes contributions from other scientific fields. Bearing this in mind, the incorporation of pottery elements from different contexts in research projects with a strong Archaeometry component will be of paramount importance. This will allow for new sets of problems to emerge, leading to the production of new scientific data. This will, in turn, help characterize the collections, both regarding their timeframe and the definition of the economic and social subsystems of the community that produced them, as well as their geographical areas of circulation, thus enabling a clarification of the territories in which they circulated and the possible "networks of exchange" among Neolithic groups. 
Acknowledgments: Acknowledgments are due to the anonymous reviewers who helped improving a first version of this text. Any errors or omissions remain my responsibility.

Funding information: This work was financed by Portuguese funds through FCT - Fundação para a Ciência e a Tecnologia in the framework of the project UIDB/00698/2020.

Conflict of interest: The author states no conflict of interest.

\section{References}

Alarcão, J. (1996). Para uma Conciliação das Arqueologias. Porto: Edições Afrontamento.

Armbruester, T. (2006). Before the monument? Ceramics with a line below the rim (A preliminary report from Vale de Rodrigo 3 , Évora). Simbolismo, arte e espaços sagrados na Pré-História da Península Ibérica (pp. 53-67). Faro: Algarve University.

Armbruester, T. (2008). Technology neglected? A painted ceramic fragment from the dated Middle Neolithic site of Vale Rodrigo 3. Vipasca, II(2), 83-94.

Boaventura, R. (2009). As antas e o megalitismo da região de Lisboa. 2 vols. (PhD thesis). Lisbon: Lisbon University.

Boaventura, R. (2011). Chronology of megalithism in South-Central Portugal. Menga. Revista de Prehistoria de Andalucía, 1, $159-190$.

Cardoso, J. L. (2015, April 7-9). A estação do Neolítico antigo do Carrascal (Oeiras, Lisboa, Portugal). In V. S. Gonçalves, M. Diniz, \& A. C. Sousa (Eds.), $5^{\circ}$. Congresso do Neolítico Peninsular. Paper presented at $V$ Congreso del Neolitic a la Península lbérica (2011, Lisbon, Portugal) (pp. 159-168). Lisbon: UNIARQ.

Cardoso, J. L., Carreira, J. R., \& Ferreira, O. V. (1996). Novos elementos para o estudo do Neolítico antigo da região de Lisboa. Estudos Arqueológicos de Oeiras, 6, 9-26.

Cardoso, J. L., \& Carvalho, A. F. (2010/2011). A Gruta da Furninha (Peniche): Estudo dos espólios das necrópoles neolíticas. Estudos Arqueológicos de Oeiras. 18, 333-392.

Cardoso, J. L., Carvalho, A. F., \& Norton, J. (1998). A estação do Neolítico Antigo de Cabranosa (Sagres, Vila do Bispo): Estudo dos materiais e integração cronológico-cultural. Arqueólogo Português, IV(16), 55-96.

Cardoso, J. L., Silva, C. T., \& Soares, J. (2008). A ocupação do Neolítico Antigo do povoado do Carrascal (Leceia, Oeiras). In J. L. Cardoso (Ed.), Homenagem a Octávio da Veiga Ferreira (pp. 247-267). Oeiras: Câmara Municipal de Oeiras.

Carreira, J. R. (1994). A Pré-História recente do Abrigo Grande das Bocas (Rio Maior). Trabalhos de Arqueologia da EAM, 2 , 47-144.

Carvalho, A. F. (1998). Abrigo da Pena d’ Água (Rexaldia, Torres Novas): Resultados das campanhas de sondagem (1992-1997). Revista Portuguesa de Arqueologia, 1(2), 39-72.

Carvalho, A. F. (2007). A Neolitização do Portugal Meridional: Os exemplos do Maciço Calcário Estremenho e do Algarve Ocidental. (PhD thesis). Faro: Algarve University.

Carvalho, A. F. (2011). Produção Cerâmica no início do Neolítico de Portugal. In J. Bernabeu Aubán, M. A. Rojo Guerra, \& L. Molina Balaguer (Eds.), Las primeras producciones cerámicas: El VI milenio cal AC en la Península Ibérica (pp. 237-252) Valencia: Departament de Prehistòria, Arqueologia i Història Antiga de la Universitat de València.

Carvalho, A. F. (2014). Bom Santo Cave in context. A preliminar contribution to the study of the first megalith builders of Southern Portugal. In A. F. Carvalho (Ed.), Bom Santo Cave (Lisbon) and the Middle Neolithic Societies of Southern Portugal (pp. 209-230). Faro: Algarve University.

Carvalho, A. F. (2016). The Pena d'Água rock-shelter (Torres Novas, Portugal): Two distinct life ways within a Neolithic sequence. In Del neolític a l'edat del bronze en el Mediterrani occidental. Estudis en homenatge a Bernat Martí Oliver (Serie de Trabajos Varios, 119, pp. 211-223). Valencia: Museo de Prehistória de Valencia.

Carvalho, A. F., \& Petchey, F. (2013). Stable isotope evidence of Neolithic Palaeodiets in the Coastal Regions of Southern Portugal. Jornal of Island and Coastal Archaeology, 8, 361-383.

Carvalho, A. F., \& Straus, L. G. (2013). New radiocarbon dates for Algarão da Goldra (Faro, Portugal): A contribution to the Neolithic of the Algarve. In J. Jiménez Ávila, M. Bustamante Álvarez, \& M. García Cabezas (Eds.), VI Encuentro de arqueología del suroeste peninsular (pp. 193-205). Villafranca de los Barros: IAM.

Conlin Hayes, E., Martínez Sánchez, R. M., \& Morgado, A. (2020). Hacia una nueva definición del Neolítico Medio en el sur de la península ibérica: Grañena Baja, Jaén. Trabajos De Prehistoria, 77(1), 30-47.

Deus, M. (2008). 0 Neolítico antigo do baixo curso do rio Sor: Os sítios Bernardo 1 e Alminho 1 (Montargil, Ponte de Sor). Promontória, 6(6), 95-114.

Diniz, M. (1994). Acerca das cerâmicas da gruta da Furninha (Peniche) e da problemática da neolitização no Centro/Sul de Portugal. Lisboa. (Master thesis). Lisbon University, Lisbon. 
Diniz, M. (2000). Neolitização e megalitismo: Arquitecturas do tempo no espaço. In V. Gonçalves (Ed.), Muitas antas, pouca gente? (pp. 105-116), Lisbon: Instituto Português de Arqueologia.

Diniz, M. (2001). Uma datação absoluta para o sítio do Neolítico antigo da Valada do Mato, Évora. Revista Portuguesa de Arqueologia, 4(2), 111-113.

Diniz, M. (2003). O Neolítico Antigo em Portugal: Investigações recentes, problemas e perspectivas. Um contributo. Arqueologia e História, 55, 35-42.

Diniz, M. (2007). O Sítio da Valada do Mato (Évora): Aspectos da neolitização no Interior/Sul de Portugal. Lisbon: Instituto Português de Arqueologia.

Diniz, M., \& Neves, C. (2018, October 24-26). 0 princípio do Neolítico no Sudoeste Peninsular (Portugal): Uma leitura (breve) dos últimos 20 anos. In S. Melro \& S. Correia (Coords.), VIII Encuentro de Arqueologia del Suroeste Peninsular. Paper presented at VIII Encuentro de Arqueologia del Suroeste Peninsular (2014, Serpa, Portugal) (pp. 315). Serpa: UNIARQ.

Ferreira, A. (2005). O sítio do Patalim (Montemor-o-Novo) no seu contexto Neolítico. (Master thesis). Lisbon University, Lisbon.

Ferreira, O. da V. (1970). Acerca dos vasos globulares com asas perfuradas e ornamentação em "falsa folha de acácia". Actas das I Jornadas Arqueológicas, 2, 227-237.

García Borja, P., Aura Tortosa, J. E., Jordá Pardo, J. F, \& Salazar-García, D. C. (2014). La cerámica neolítica de la Cueva de Nerja (Málaga, España): Salas del Vestíbulo y la Mina. Archivo de Prehistoria Levantina, XXX, 81-131.

Guilaine, J., \& Ferreira, O. da V. (1970). Le Néolithique ancien au Portugal. Bulletin de la Societé Préhistórique Française, 67(I), 304-322.

Hodder, I. (1982). Symbols in action. Ethnoarchaeological studies of material culture. Cambridge: Cambridge University Press.

Manen, C. (2002). Structure et identité des styles céramiques du Néolithique ancien entre Rhône et Èbre. Gallia préhistoire, 44, $121-165$.

Mataloto, R., \& Boaventura, R. (2009). Entre vivos e mortos nos IV e III milénios a.n.e. do Sul de Portugal: Um balanço relativo do povoamento com base em datações pelo radiocarbono. Revista Portuguesa de Arqueologia, 12(2), 39-77.

Neves, C. (2010). Monte da Foz 1 (Benavente): Um episódio da Neolitização na margem esquerda do Baixo Tejo. (Master thesis). Lisbon University, Lisbon.

Neves, C. (2015a). A cerâmica decorada com sulco abaixo do bordo do sítio neolítico do Monte da Foz 1 (Benavente, Portugal). In I. Saéz de la Fuente, C. Tejerizo García, L. Elorza González de Alaiza, B. Hernández Beloqui, C. Hernando Álvarez (Coords.), Arqueologías sociales. Arqueología en sociedad (pp. 458-465). Vitoria-Gasteiz: Arkeogazte-JAS Arqueología.

Neves, C. (2015b, April 7-9). A $2^{a}$ metade do V Milénio no Ocidente Peninsular: Algumas problemáticas a partir da cultura material. In V. S. Gonçalves, M. Diniz, \& A. C. Sousa (Eds.), $5^{\circ}$. Congresso do Neolítico Peninsular. Paper presented at $V$ Congreso del Neolitic a la Península Ibérica (2011, Lisbon, Portugal) (pp. 314-321). Lisbon: UNIARQ.

Neves, C. (2016). A produção cerâmica na segunda metade do $5^{\circ}$ milénio AC: Leitura(s) a partir do Monte da Foz 1 (Benavente, Portugal). In I. P. Coelho, J. B. Torres, L. S. Gil, T. Ramos (Eds.), Entre ciência e cultura: Da interdisciplinaridade à transversalidade da arqueologia (pp. 87-97). Lisboa: CHAM-FCSH/UNL-UAç e IEM-FCSH/UNL.

Neves, C. (2018). O Neolítico médio no Ocidente Peninsular: O sítio da Moita do Ourives (Benavente), no quadro do povoamento do $5^{\circ}$ e $4^{\circ}$ milénio AC. 2 vols. (PhD thesis). Lisbon University, Lisbon.

Neves, C., \& Diniz, M. (2014). Acerca dos cenários da acção: Estratégias de implantação e exploração do espaço nos finais do $5^{\circ}$ e na primeira metade do $4^{\circ}$ milénio AC, no Sul de Portugal. Estudos do Quaternário, 11, 45-58.

Neves, C., Rodrigues, F., \& Diniz, M. (2008a). Moita do Ourives - um sítio do Neolítico médio no Baixo Tejo (Benavente, Portugal): Matérias-primas e cultura material. In M. Hernández Perez, J. Soler Díaz, J. López Padilla (Eds.), IV Congreso del Neolítico Peninsular (Vol. 2, pp. 216-221). Alicante: MARQ.

Neves, C., Rodrigues, F., \& Diniz, M. (2008b). Neolithisation process in lower Tagus valley left bank: Old perspectives and new data. In M. Diniz (Ed.), Early Neolithic in the Iberian Peninsula: Regional and transregional components (Bar International Series 1857, pp. 43-51). Lisbon: UISPP.

Nukushina, D. (2015, April 7-9). A presença da decoração "falsa folha de acácia" nas cerâmicas do Neolítico antigo: 0 caso do Abrigo Grande das Bocas (Rio Maior, Portugal). In V. S. Gonçalves, M. Diniz, \& A. C. Sousa (Eds.), $5 .^{\circ}$ Congresso do Neolítico Peninsular. Paper presented at V Congreso del Neolitic a la Península Ibérica (2011, Lisbon, Portugal) (pp. 419-428). Lisbon: UNIARQ.

Nunes, A., \& Carvalho, A. F. (2013). O Neolítico Médio no Maciço Calcário Estremenho: Estado actual dos conhecimentos e perspectivas de investigação futura. In J. M. Arnaud, A. Martins, \& C. Neves (Eds.), Arqueologia em Portugal - 150 anos (pp. 329-334). Lisbon: Associação dos Arqueólogos Portugueses.

Rocha, L. (2007). Relatório de escavação do sítio arqueológico da Hortinha 1 (Torre de Coelheiros, Évora). Hortinha 1 - excavation report. Évora: Arkeo Habilis.

Reimer, P., Bard, E., Bayliss, A., Beck, J., Blackwell, P., Ramsey, C., ... Van der Plicht, J. (2013). IntCal13 and Marine13 radiocarbon age calibration curves 0-50,000 years cal BP. Radiocarbon, 55(4), 1869-1887. doi: 10.2458/azu_js_rc.55.16947.

Simões, T. (1999). O sítio neolítico de São Pedro de Canaferrim, Sintra. Contribuições para o estudo da Neolitização da Península de Lisboa. Lisbon: Instituto Português de Arqueologia.

Simões, T. (2003). A ocupação do Neolítico antigo de São Pedro de Canaferrim: Novos dados em perspectiva. In V.S. Gonçalves (Ed.), Muita gente, poucas antas? Origens, espaços e contextos do Megalitismo (pp. 115-134). Lisbon: Instituto Português de Arqueologia. 
Silva, C. T., \& Soares, J. (1980). O Neolítico da Comporta. Descobertas Arqueológicas no Sul de Portugal, 13-17.

Silva, C. T., \& Soares, J. (1981). Pré-história da área de Sines. Lisboa: Gabinete da Área de Sines.

Silva, C. T., \& Soares, J. (2004). Intervenção arqueológica no sítio neolítico do Brejo Redondo (Sines). Musa, Museus, Arqueologia e Outros Patrimónios, 1, 83-105.

Silva, C. T., \& Soares, J. (2014). 0 habitat do Neolítico antigo do Casal da Cerca (Palmela). Setúbal Arqueológica, 15, 61-104.

Silva, C. T., \& Soares, J. (2018). Para o estudo do Neolítico Médio: 0 sítio da Fábrica de Celulose (Mourão). Revista Portuguesa de Arqueologia, 21, 5-23.

Silva, C. T., Soares, J., \& Coelho-Soares, A. (2010, November 28-29). Arqueologia de Chãos de Sines. Novos elementos sobre o povoamento Pré-histórico. In I. Silva, J. Madeira, \& S. Ferreira (Eds.), Actas do $2^{\circ}$ encontro de História do Alentejo Litoral. Paper presented at $2^{\circ}$ encontro de História do Alentejo Litoral (2009, Sines, Portugal) (pp. 11-34). Sines: Centro Cultural Emmérico Nunes.

Soares, J., \& Silva, C. T. (2013). Economia agro-marítima na Pré-História do estuário do Sado. Novos dados sobre o Neolítico da Comporta. In J. Soares (Ed.), Pré-história das Zonas Húmidas. Paisagens de Sal (pp. 145-170). Setúbal: MAEDS.

Urquijo, J. G., Estévez, J. J. I., Peña, L. Z., \& Chocarro, L. P. (2001). Estudio etnoarqueológico sobre la cerámica Gzaua (Marruecos): Técnica y contexto social de un artesanado arcaico. Trabajos de PreHistoria, 58(1), 5-27.

Valera, A. C. (2013). Cronologia dos Recintos de Fossos da Pré-História recente em território português. In J. M. Arnaud, A. Martins, \& C. Neves (Eds.), Arqueologia em Portugal - 150 anos (pp. 345-350). Lisbon: Associação dos Arqueólogos Portugueses.

Vera Rodríguez, J. C., \& Martínez Fernández, M. J. (in press). El yacimiento neolítico del arroyo de Santa María (Almonte, Huelva). In G. Martínez Fernández, J. Afonso Marrero, A. Dorado Alejos, C. Bashore Acero, F. Martínez Sevilla, \& J. A. Cámara Serrano (Eds.), Actas del VI Congreso del Neolítico en la Península lbérica. Granada, 22-24 de junio de 2016.

Zilhão, J. (1992). Gruta do Caldeirão. O Neolítico Antigo. Lisbon: Instituto Português do Património Arquitectónico e Arqueológico.

Zilhão, J., \& Carvalho, A. F. (1996). O Neolítico do Maciço Calcário Estremenho: Crono-estratigrafia e povoamento. Actes del I Congreso del Neolitic a la Península Ibérica. Rubricatum. Paper presented at I Congreso del Neolitic a la Península Ibérica (Gavà, Spain) (pp. 659-671). Gavà: Museu de Gavà, I. 